\title{
Giant toads Bufo marinus in Australia and Venezuela have antibodies against 'ranaviruses'
}

\author{
Z. Zupanovic ${ }^{1}$, G. Lopez ${ }^{2}$, A. D. Hyatt ${ }^{1, *}$, B. Green ${ }^{3}$, G. Bartran ${ }^{3}$, H. Parkes ${ }^{1}$, \\ R. J. Whittington ${ }^{4}$, R. Speare ${ }^{5}$ \\ ${ }^{1}$ CSIRO, Division of Animal Health, Australian Animal Health Laboratory, PO Bag 24, Geelong 3220, Victoria, Australia \\ ${ }^{2}$ Centro de Microbiologia y Biologia Celular, Instituto Venezolano de Investigaciones Cienticas, Apartado Postal 21827, \\ Caracas, Venezuela \\ ${ }^{3}$ CSIRO, Division of Wildlife and Ecology, PO Box 84, Lyneham, Canberra 2602, Australia \\ ${ }^{4}$ Elizabeth Macarthur Agricultural Institute, PMB 8, Camden 2570, New South Wales, Australia \\ ${ }^{5}$ Department of Public Health and Tropical Medicine, James Cook University, Townsville 4811, Queensland, Australia
}

\begin{abstract}
A serological survey was conducted for antibodies against 'ranaviruses' in the giant toad Bufo marinus in Australia and Venezuela. Sera contannng antibodies against 'ranaviruses' were found in both countries. In Australia positive antibodies were identified in populations throughout most of the known range of $B$. marinus. Results were confirmed by immunofluorescence and immunoelectron microscopy where a characteristic staning pattern of 'ranaviruses' in infected cells was observed. Whilst a 'ranavirus(es)' has been isolated from populations of $B$. marinus in Venezuela, no virus has been isolated from Australian B. marinus populations. The significance of 'ranavirus' sero-positive B. marinus in Australia is discussed
\end{abstract}

KEY WORDS: Giant toads B Bufo marinus Australia - Venezuela - Ranaviruses

\section{INTRODUCTION}

The family Iridoviridae encompasses 5 genera: Iridovirus, Chloriridovirus, Ranavirus, Lymphocystivirus and the 'goldfish virus 1-like viruses' (Goorha 1995).

Ranaviruses have been isolated from fish and amphibians (Ahne et al. 1997, Zupanovic et al. 1998). Affected species include the common frog Rana temporaria and toad Bufo bufo in the United Kingdom (Drury et al. 1995, Cunningham 1996), the leopard frog $R$. pipiens and the American bullfrog $R$. catesbeiana in North America (Granoff et al. 1966, Wolf et al. 1968), R. esculenta in Croatia (Fijan et al. 1991) and the giant toad B. marinus in Venezuela (Zupanovic et al. 1998). In Australia, 2 ranaviruses have been identified. Bohle iridovirus (BIV) was isolated from the ornate burrowing frog Limnodynastes ornatus (Speare \& Smith 1992 , Hengstberger et al. 1993) and epizootic haematopoi-

\footnotetext{
- Addressee for correspondence.
}

E-mail: alex@aahl.dah.csiro.au etic necrosis virus (EHNV) (Langdon et al. 1986) from redfin perch Perca fluviatilis. The significance of ranaviruses has been recognised by Hengstberger et al. (1993), Cunningham (1996), Zupanovic et al. (1998), and Whittington \& Hyatt (1997) in areas of ornamental fish trade, impact on wild and commercial fish populations and the international trade in amphibians. Inherent in these areas is the concern about the unregulated transport of ranaviruses and the possible associated spread of disease (Laurance et al. 1996, Ahne et al. 1997).

In 1935 Bufo marinus, known in Australia as the cane toad, was imported from Hawail in an attempt to control insect pests of sugar cane. The toads were imported to Gordonvale (Queensland), bred at Meringa (Queensland) and the progeny released in areas around Cairns, Gordonvale and Innisfail (Tyler 1994). The toad's range expanded rapidly through north and east Queensland (Easteal 1983) and into New South Wales and the Northern Territory (Fig. 1). The dense populations of toads and their rapidly expanding range 


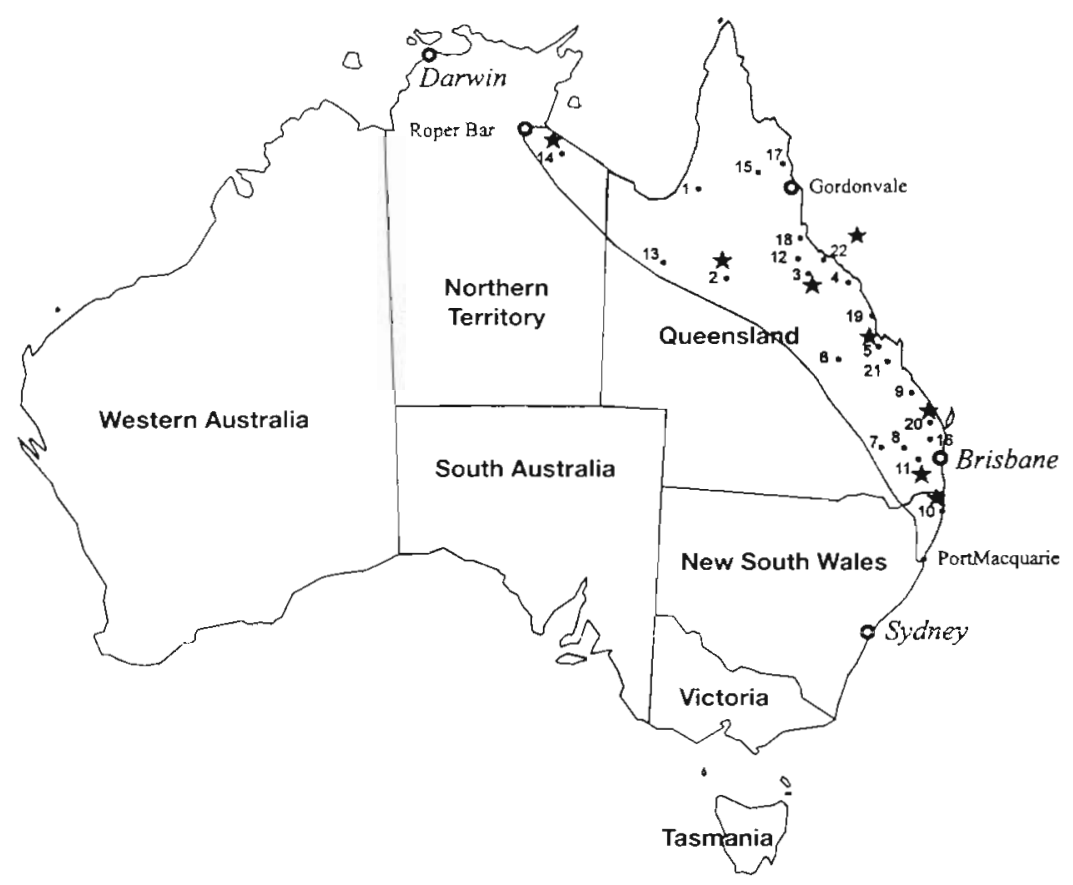

$\begin{array}{lll}1 & \text { Normanton } & 12 \text { Dotswood Station } \\ 2 & \text { Richmond } & 13 \text { Mt Isa } \\ 3 & \text { Charters Towers } & 14 \text { Borroloola } \\ 4 & \text { Bowen } & 15 \text { Mareeba } \\ 5 & \text { Marlborough } & 16 \text { Gympie } \\ 6 \text { Emerald } & 17 \text { Mossman } \\ 7 \text { Chinchilla } & 18 \text { Ingham } \\ 8 \text { Kingaroy } & 19 \text { Mackay } \\ 9 \text { Miriam Vale } & 20 \text { Tiaro } \\ 10 \text { Lennox Head } & 21 \text { Tilpal Station } \\ 11 \text { Boonah } & 22 \text { Townsville }\end{array}$

Fig. 1. Distribution of Bufo marinus in Australia and sites of serum collection. Shaded area represents known distribution of $B$. marinus. Stars represent locations where positive sera were identified

are attributed to abundant food and the lack of coevolved predators and pathogens. Within Australia the toad is considered a threat to indigenous vertebrates (Covacevich \& Archer 1975, Freeland 1985, 1986, 1987). Toads are toxic to predators at all stages of their life cycle; they may compete for food and also act as predators on native fauna. Until recently the transmission of infectious agents from toads was not considered a major threat to Australia's vertebrates.

The significance of the toad's expanding geographical range in respect to the transmission of disease(s) was noted by Hengstberger et al. (1993). These authors speculated that if cane toads are, or have the potential to behave as, vectors for ranaviruses then there is potential for a significant environmental impact. This speculation was supported by subsequent work which showed that BIV was pathogenic to barramundi Lates calcarifer and 2 native Australian frog species, Limnodynastes terraereginae and Litoria latopalmata (Moody \& Owens 1994, Culler et al. 1995). Collectively, the transmission work involving BIV has shown that this ranavirus can infect a range of species and is pathogenic to both amphibians and fish. As BIV is a pathogenic virus to a broad range of species, and as $B$. marinus is expanding its distribution, it is important to know if populations of free-ranging $B$. marinus have been exposed to any 'ranaviruses'.

Work by Whittington \& Speare (unpubl. data 1993) indicated that free-ranging cane toads in Townsville (Queensland) had serological evidence of infection with a ranavirus. In this paper we present data on the prevalence of antibodies to 'ranaviruses' in the sera of free-ranging Bufo marinus in Australia and Venezuela, and show that infection with 'ranaviruses' is widespread in both countries. The possible implications of these results are discussed.

\section{MATERIALS AND METHODS}

Collection of sera. For Australian toads, there were a total of 1115 samples collected from 22 locations throughout the known range of Bufo marinus during 1993, 1994, 1996 and 1997. A total of 240 sera from $B$. marinus in Venezuela were also examined. Blood was collected by cardiac puncture from free-ranging B. marinus in Australia and Venezuela (Figs. 1 \& 2), placed into sterile tubes and allowed to clot at room temperature (RT). Serum was separated by centrifugation ( $800 \times \mathrm{g}$ for $10 \mathrm{~min}$ ) and stored at $-20^{\circ} \mathrm{C}$.

Detection of antibodies. ELISA for detection of antiranavirus antibody in toad sera: Sera collected from both Australia and Venezuela were tested at the Australian Animal Health Laboratory (AAHL). Sera collected from the Townsville area of Queensland, Australia, were tested at the Elizabeth Macarther Agricultural Institute (EMAI). The ELISA assays used at the respective laboratories are described below.

At AAHL, the antibody capture ELISA was performed as described below. The toad antibodies used in the ELISA react against EHNV, BIV and Guatopo virus (GV) (unpubl. data). Microtitre plates (Dynatech) were coated with sheep anti-EHNV serum in coating buffer $(0.05 \mathrm{M}$ Tris- $\mathrm{HCl}, 0.15 \mathrm{M} \mathrm{NaCl}, \mathrm{pH} 9)$, incubated 


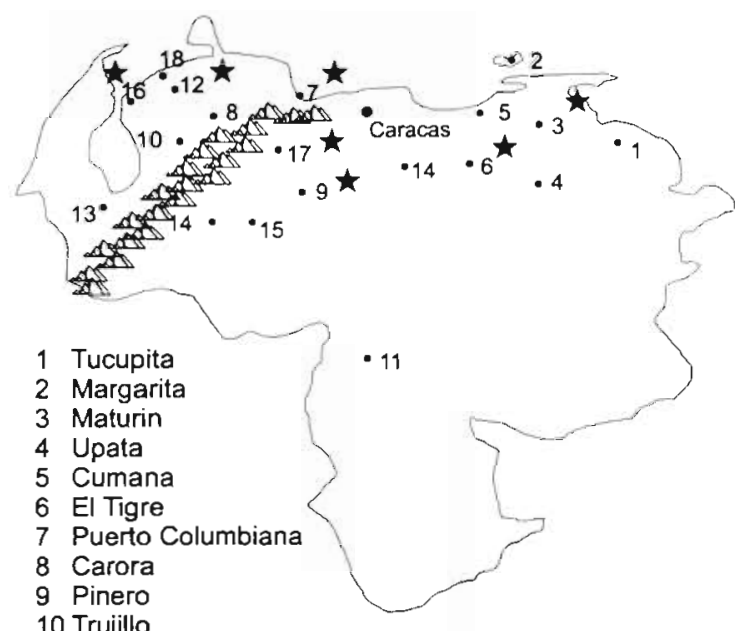

11 Puerto Ayacucho

12 Urumaco

13 El Vigia

14 Guatopo

15 Bruzual

16 Altagracia

17 Quibor

18 Quisira

overnight at $4^{\circ} \mathrm{C}$ and washed $(\times 3)$ in phosphatebuffered saline with $0.05 \% \mathrm{v} / \mathrm{v}$ Tween 20 (PBST). Freebinding sites were blocked with $2 \%$ gelatin in PBST ( $30 \mathrm{~min}, 37^{\circ} \mathrm{C}$ ), washed in PBST, and then incubated with EHNV $\left(60 \mathrm{~min}, 37^{\circ} \mathrm{C}\right)$. Following incubation, the plates were washed $(\times 3)$ in PBST and incubated toad sera added for $60 \mathrm{~min}$ at $37^{\circ} \mathrm{C}$. Following a further 3 washes in PBST, rabbit antisera against IgG were added $\left(60 \mathrm{~min}, 37^{\circ} \mathrm{C}\right)$. Plates were again washed in PBST and incubated with toad anti-rabbit IgG serum conjugated to horseradish peroxidase (Silenus) in PBST with $2 \%$ gelatine $\left(60 \mathrm{~min}, 37^{\circ} \mathrm{C}\right)$. After a final wash $42 \mathrm{mmol} \mathrm{I}^{-1} 3,3^{\prime}, 5,5^{\prime}$ tetramethyl benzidine in DMSO, citrate acetate buffer pH 5.9 and $3 \% \mathrm{H}_{2} \mathrm{O}_{2}$ was added. The reaction was stopped after $10 \mathrm{~min}$ (RT) by the addition of $1 \mathrm{M} \mathrm{H}_{2} \mathrm{SO}_{4}\left(50 \mu\right.$ well $\left.^{-1}\right)$. Optical densities (OD) were measured at $450 \mathrm{~nm}$ (Labsystems Multiscan MS plate reader).

At EMAI the ELISAs were performed as described by Whittington et al. (1997). Reagent volumes were $100 \mu \mathrm{l}$ per well unless otherwise stated. Purified rabbit antibodies against EHNV were diluted in borate buffer $(100 \mathrm{mM}$ boric acid, $25 \mathrm{mM}$ disodium tetraborate, $75 \mathrm{mM}$ $\mathrm{NaCl}, \mathrm{pH} 8.4$ ), added to polystyrene microtitre plates (Linbro, Flow ICN) and incubated overnight at $4^{\circ} \mathrm{C}$. Free-binding sites were then blocked using PBST and $1 \% \mathrm{w} / \mathrm{v}$ ovalbumin, incubated for $30 \mathrm{~min}$ at RT. After washing plates $(\times 5)$ in distilled water with $0.05 \% \mathrm{v} / \mathrm{v}$ Tween 20, cell culture supernatant containing 104.5 to 106.1 TCID $_{50} \mathrm{ml}^{-1}$ of either EHNV or BIV was added to each well and incubated for $60 \mathrm{~min}$ at RT. After washing plates as above, serum of Bufo marinus, which had been diluted in PBST with $0.1 \% \mathrm{w} / \mathrm{v}$ ovalbumin (PBSTO) and stored overnight at $4^{\circ} \mathrm{C}$, was added and incubated for 60 min at RT. After washing as above, sheep antiserum against B. marinus IgG, diluted in PBSTO, was added and incubated for $60 \mathrm{~min}$ at RT. This was followed after washing by rabbit anti-sheep-immunoglobulin horse radish peroxidase conjugate (KPL Laboratories) diluted $1: 3000$ in PBSTO and incubated for $60 \mathrm{~min}$ at RT. After washing, the chromogen 2,2'-azino-bis(3-ethyl-benzthiazoline-6-sulphonic acid) (ABTS) was added and the plate was incubated at RT on a shaker. The reaction was stopped after $13 \mathrm{~min}$ by the addition of $0.01 \% \mathrm{w} / \mathrm{V}$ sodium azide in $0.1 \mathrm{M}$ citric acid. Absorbance was read at $450 \mathrm{~nm}$ without blanking the plate.

All sera were tested with and without ranavirus antigen to confirm the specificity of the reaction.

Immunofluorescence and immunoelectron microscopy: A random sample of toad field sera was tested by immunofluorescence to confirm the validity of the ELISA results. Confluent monolayers of Chinook salmon embryo cells (CHSE-214, ATCC CRL 1681) were infected with BIV (106.5 $\left.\mathrm{TCID}_{50} \mathrm{ml}^{-1}\right)$. At $48 \mathrm{~h}$ post infection, when approximately $50 \%$ of cells showed a cytopathic effect, cells were fixed in cold $\left(-20^{\circ} \mathrm{C}\right) \mathrm{ab}-$ solute methanol $(3 \mathrm{~min})$ followed by cold $\left(-20^{\circ} \mathrm{C}\right)$ acetone ( $3 \mathrm{~min}$ ). Cells were rehydrated in PBSA with $1 \%$ BSA and Australian field serum (Table 1) added for $45 \mathrm{~min}$ at $37^{\circ} \mathrm{C}$. Following incubation, the cells were washed $(\times 3)$ in $\mathrm{PBSA}$ with $1 \% \mathrm{BSA}$, incubated with (1:100) rabbit anti-toad IgG serum (45 min, $37^{\circ} \mathrm{C}$ ), washed $(\times 3)$ in PBSA with $1 \%$ BSA and then incubated with $(1: 100)$ sheep anti-rabbit Ig-FITC conjugate $\left(45 \mathrm{~min}\right.$ at $\left.37^{\circ} \mathrm{C}\right)$. After a final wash $(\times 3)$ the cells were covered with $50 \%$ glycerol in PBSA/1\% BSA and viewed with a Leica Reichert Polyvar light microscope.

BIV was purified as described by Hengstberger et al. (1993) and adsorbed to carbon-coated, parlodion filmed, 400 mesh gold grids. The grids were washed in $1 \%$ cold water fish gelatin (Sigma) in PBS for $10 \mathrm{~min}$. Field serum from Bufo marinus (Marlborough) were added to the grids (1:1000) for $60 \mathrm{~min}$ at RT. Grids were washed $(\times 6)$ in PBS, incubated in rabbit anti-toad IgG (60 min, RT), washed $(\times 6)$ in PBS and then incubated with $10 \mathrm{~nm}$ protein A-gold (60 min, RT). Grids were then washed $(\times 6)$ in $\mathrm{PBS}$, stained with $2 \%$ phosphotungstic acid ( $\mathrm{pH} 6.8$ ) and viewed in a Hitachi scanning transmission electron microscope at $75 \mathrm{kV}$.

\section{RESULTS}

\section{Antibody capture ELISA}

The overall prevalence of antibodies to 'ranaviruses' in Australia was low (2.7\%) (Table 1). However, in the 
Table 1. Serological survey of Australian cane toads. FAT: fluorescent antibody tests. Numbers are no positive/no. tested

\begin{tabular}{|c|c|c|c|c|c|c|}
\hline Region & Location & $\begin{array}{l}\text { Location } \\
\text { prevalence } \\
\text { (ELISA) }\end{array}$ & $\begin{array}{l}\text { Location } \\
\text { numbers } \\
\text { (ELISA) }\end{array}$ & FAT & $\begin{array}{l}\text { Total regional } \\
\text { numbers } \\
\text { (ELISA) }\end{array}$ & $\begin{array}{l}\text { Total regional } \\
\text { prevalence } \\
\text { (ELISA) }\end{array}$ \\
\hline Northern NSW & Lenox Head $\left(28.47^{\circ} \mathrm{S}, 153.35^{\circ} \mathrm{E}\right)$ & $0.4 \%$ & $1 / 255$ & - & $1 / 255$ & $0.4 \%$ \\
\hline S-E Queensland & $\begin{array}{l}\text { Boonah }\left(28.00^{\circ} \mathrm{S}, 152.36^{\circ} \mathrm{E}\right) \\
\text { Gympie }\left(26.10^{\circ} \mathrm{S}, 152.35^{\circ} \mathrm{E}\right) \\
\text { Kingaroy }\left(26.32^{\circ} \mathrm{S}, 151.50^{\circ} \mathrm{E}\right)\end{array}$ & $\begin{array}{r}18 \% \\
0 \% \\
0 \%\end{array}$ & $\begin{array}{l}6 / 33 \\
0 / 23 \\
0 / 29\end{array}$ & $\frac{1 / 1}{0 / 1}$ & $6 / 85$ & $7.1 \%$ \\
\hline $\begin{array}{l}\text { Central } \\
\text { Queensland }\end{array}$ & $\begin{array}{l}\text { Chinchilla }\left(26.42^{\circ} \mathrm{S}, 150.35^{\circ} \mathrm{E}\right) \\
\text { Emerald }\left(23.30^{\circ} \mathrm{E}, 148.08^{\circ} \mathrm{E}\right) \\
\text { Marlborough }\left(22.51^{\circ} \mathrm{S}, 159.50^{\circ} \mathrm{E}\right) \\
\text { Miriam Vale }\left(24.17^{\circ} \mathrm{S}, 151.34^{\circ} \mathrm{E}\right) \\
\text { Tilpal Station }\left(22.50^{\circ} \mathrm{S}, 150.10^{\circ} \mathrm{E}\right. \\
\text { Tiaro }\left(25.43^{\circ} \mathrm{S}, 152.34^{\circ} \mathrm{E}\right)\end{array}$ & $\begin{array}{l}0 \% \\
0 \% \\
8 \% \\
0 \% \\
0 \% \\
2 \%\end{array}$ & $\begin{array}{l}0 / 2 \\
0 / 27 \\
9 / 116 \\
0 / 33 \\
0 / 47 \\
2 / 86\end{array}$ & $\begin{array}{l}- \\
- \\
1 / 1 \\
- \\
0 / 1 \\
2 / 2\end{array}$ & $11 / 311$ & $3.5 \%$ \\
\hline $\begin{array}{l}\text { Northern } \\
\text { Queensland } \\
\text { (coast) }\end{array}$ & $\begin{array}{l}\text { Bowen }\left(20.00^{\circ} \mathrm{S}, 148.10^{\circ} \mathrm{E}\right) \\
\text { Charters Towers }\left(20.02^{\circ} \mathrm{S}, 146.20^{\circ} \mathrm{E}\right) \\
\text { Dotswood Station }\left(19.50^{\circ} \mathrm{S}, 146.55^{\circ} \mathrm{E}\right) \\
\text { Ingham }\left(18.36^{\circ} \mathrm{S}, 146.12^{\circ} \mathrm{E}\right) \\
\text { Mackay }\left(21.10^{\circ} \mathrm{S}, 149.10^{\circ} \mathrm{E}\right) \\
\text { Mossman }\left(16.21^{\circ} \mathrm{S}, 145.15^{\circ} \mathrm{E}\right) \\
\text { Townsville }\left(19.13^{\circ} \mathrm{S}, 146.48^{\circ} \mathrm{E}\right)\end{array}$ & $\begin{array}{r}0 \% \\
0 \% \\
0 \% \\
0 \% \\
0 \% \\
0 \% \\
14 \%\end{array}$ & $\begin{array}{l}0 / 200 \\
1 / 11 \\
0 / 22 \\
0 / 38 \\
0 / 20 \\
0 / 23 \\
3 / 21\end{array}$ & $\begin{array}{l}1 / 1 \\
- \\
- \\
- \\
- \\
- \\
-\end{array}$ & $4 / 335$ & $1.2 \%$ \\
\hline $\begin{array}{l}\text { Northern } \\
\text { Queensland } \\
\text { (inland) }\end{array}$ & $\begin{array}{l}\text { Mareeba }\left(17.00^{\circ} \mathrm{S}, 145.28^{\circ} \mathrm{E}\right) \\
\text { Mt Isa }\left(20.50^{\circ} \mathrm{S}, 139.29^{\circ} \mathrm{E}\right) \\
\text { Richmond }\left(20.45^{\circ} \mathrm{S}, 143.05^{\circ} \mathrm{E}\right)\end{array}$ & $\begin{array}{r}17 \% \\
0 \% \\
4 \%\end{array}$ & $\begin{array}{l}4 / 24 \\
0 / 27 \\
1 / 24\end{array}$ & $\begin{array}{l}1 / 1 \\
- \\
-\end{array}$ & $5 / 75$ & $6.7 \%$ \\
\hline Gulf country & Normanton $\left(17.40^{\circ} \mathrm{S}, 141.05^{\circ} \mathrm{E}\right)$ & $0 \%$ & $0 / 31$ & - & $0 / 31$ & $0 \%$ \\
\hline Northern Territory & Borroloola $\left(16.00^{\circ} \mathrm{S}, 136.15^{\circ} \mathrm{E}\right)$ & $13 \%$ & $3 / 23$ & $1 / 1$ & $3 / 23$ & $13 \%$ \\
\hline
\end{tabular}

locations where sero-positive samples were identified, prevalence varied from $0.4 \%$ at Lennox Head (New South Wales) to $18 \%$ at Boonah (Queensland). The locations where sera were collected were divided into 7 broad regions, northern New South Wales (Nth NSW), south-east Queensland (S-E Qld), central Queensland (C. Qld), northern Queensland (coastal and inland), Gulf country, Northern Territory (NT), and (Table 1). Antibody-positive sera to 'ranaviruses' were identified in all regions except the Gulf country (0/31). Fig. 1 shows the geographical location of sero-positive samples. The distribution extends from Lennox Head (NSW) to Borroloola (Northern Territory)

A total of 240 sera from Bufo marinus in Venezuela were examined with an overall antibody prevalence of $8.3 \%$. The samples came from 18 different localities. The prevalence of positive sera varied from 6 to $27 \%$ (Table 2). Positive sera were identified in the northern regions of Venezuela, both east and west of the Andes (Fig. 2).

\section{Immunofluorescence and immunoelectron microscopy}

A small number of field sera was examined by immunofluorescence; the number was limited by the availability of sera. This procedure served as a positive control for the ELISA assays. The ELISA positive samples returned positive immunofluorescence results. Intracellular fluorescent foci and aggregates were observed within the cytoplasm; extracellular foci were also observed (Fig. 3A). Infected cells incubated with

Table 2. Serological survey of Venezuelan cane toads. na: sample size too small for valid interpretation (percent prevalence). Numbers are no. positive/no. tested

\begin{tabular}{|lcr|}
\hline Location & $\begin{array}{c}\text { Total numbers } \\
\text { (ELISA) }\end{array}$ & $\begin{array}{c}\text { Total } \\
\text { prevalence }\end{array}$ \\
\hline Cumana $\left(10.29^{\circ} \mathrm{N}, 64.12^{\circ} \mathrm{W}\right)$ & $0 / 16$ & $0 \%$ \\
Puerto Columbiana $\left(10.55^{\circ} \mathrm{N}, 67.65^{\circ} \mathrm{W}\right)$ & $5 / 22$ & $23 \%$ \\
Maturin $\left(9.45^{\circ} \mathrm{N}, 63.10^{\circ} \mathrm{W}\right)$ & $3 / 11$ & $27 \%$ \\
Guatopo $\left(10.12^{\circ} \mathrm{N}, 66.80^{\circ} \mathrm{W}\right)$ & $0 / 23$ & $0 \%$ \\
Altagracia $\left(10.44^{\circ} \mathrm{N}, 71.30^{\circ} \mathrm{W}\right)$ & $1 / 3$ & na \\
Carora $\left(10.12^{\circ} \mathrm{N}, 70.30^{\circ} \mathrm{W}\right)$ & $0 / 3$ & $0 \%$ \\
Puerte $A y a c u c h o\left(5.39^{\circ} \mathrm{N}, 67.32^{\circ} \mathrm{W}\right)$ & $0 / 22$ & $0 \%$ \\
Quibor $\left(9.55^{\circ} \mathrm{N}, 69.35^{\circ} \mathrm{W}\right)$ & $1 / 3$ & $\mathrm{na}$ \\
Quisira $\left(10.54^{\circ} \mathrm{N}, 71.17^{\circ} \mathrm{W}\right)$ & $0 / 2$ & $0 \%$ \\
Upata $\left(8.02^{\circ} \mathrm{N}, 62.25^{\circ} \mathrm{W}\right)$ & $0 / 4$ & $0 \%$ \\
Trujilo $\left(9.20^{\circ} \mathrm{N}, 70.38^{\circ} \mathrm{W}\right)$ & $1 / 16$ & $6 \%$ \\
El Vigia $\left(8.44^{\circ} \mathrm{N}, 64.18^{\circ} \mathrm{W}\right)$ & $0 / 2$ & $0 \%$ \\
Pinero $\left(8.90^{\circ} \mathrm{N}, 68.12^{\circ} \mathrm{W}\right)$ & $2 / 22$ & $9 \%$ \\
Urumaco $\left(11.21^{\circ} \mathrm{N}, 71.20^{\circ} \mathrm{W}\right)$ & $3 / 20$ & $15 \%$ \\
Bruzual $\left(8.03^{\circ} \mathrm{N}, 69.20^{\circ} \mathrm{W}\right)$ & $0 / 21$ & $0 \%$ \\
Tucupita $\left(9.02^{\circ} \mathrm{N}, 62.04^{\circ} \mathrm{W}\right)$ & $0 / 19$ & $0 \%$ \\
El Tigre $\left(8.44^{\circ} \mathrm{N}, 64.18^{\circ} \mathrm{W}\right)$ & $4 / 22$ & $18 \%$ \\
Margarita $\left(11^{\circ} \mathrm{N}, 64^{\circ} \mathrm{W}\right)$ & $0 / 9$ & $0 \%$ \\
\hline
\end{tabular}



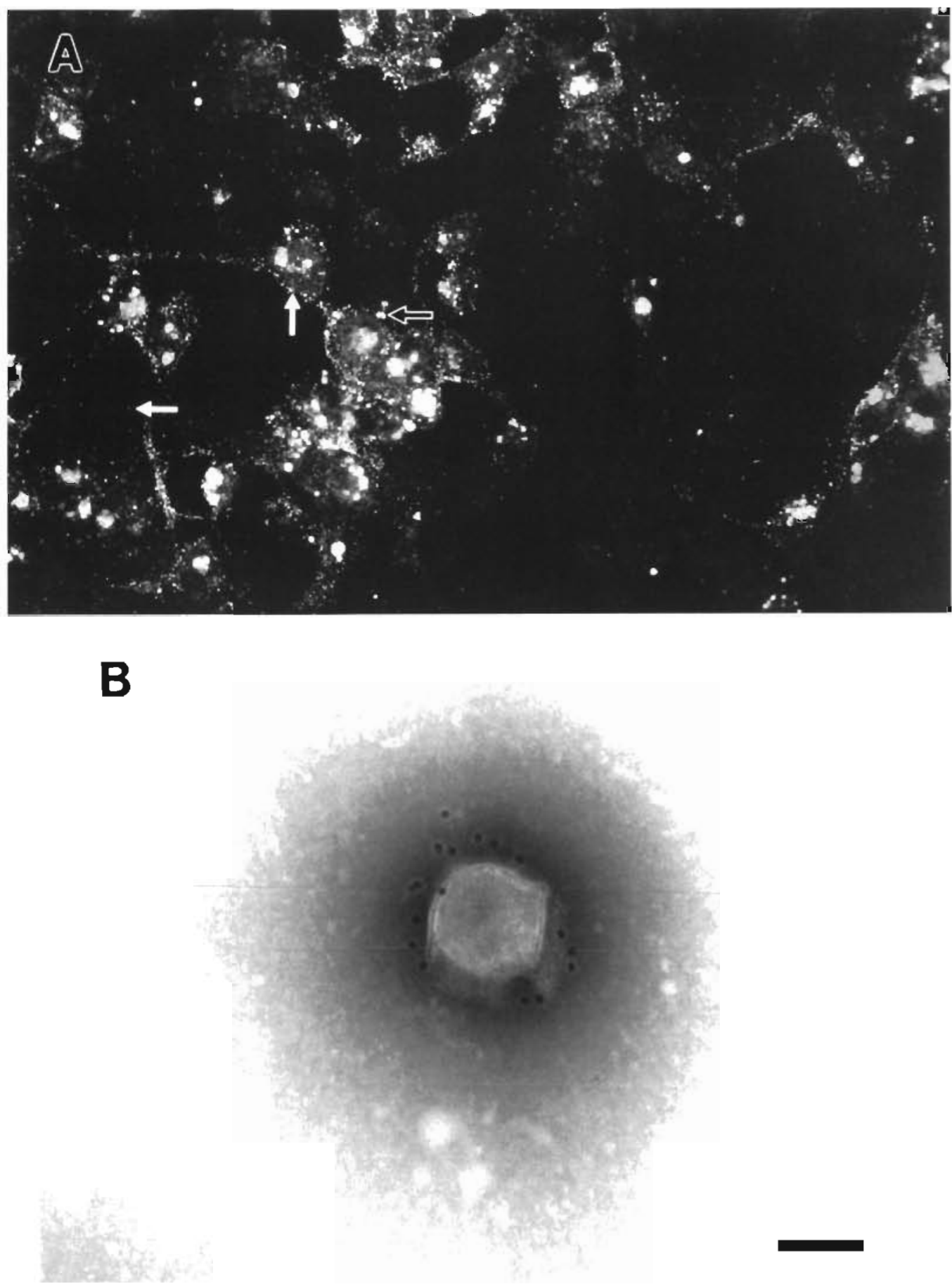

Fig. 3. (A) Representative immunofluoresence of BIV-infected cells incubated with toad serum (Marlborough) that was positive by antibody capture ELISA. White arrows indicate intra- and extracellular viruses. Open arrow indicates virus aggregates/ matrix. (B) Transmission electron micrograph of BIV negatively stained with phosphotungstic acid. The virus had been incubated with toad sera from a free-ranging toad (Marlborough), rabbit anti-toad IgG and protein A-gold. Scale bar $=100 \mathrm{~nm}$

ELISA negative sera were negative, i.e. no fluorescent patterns were observed. When field serum were incubated with purified BIV, viruses were specifically goldlabelled. Very little, if any, background labelling was observed (Fig. 3B).

\section{DISCUSSION}

The tests used in this study detected antibodies in toad sera against viruses that have been tentatively assigned to the genus Ranavirus. To date, toad sera 
from 22 different locations have been tested for the presence of antibodies. Of these, a total of 30 sera from 9 locations, representing 6 regions of north-eastern Australia, have been identified as positive. With the exception of the Gulf country, these geographical locations represent most of the known range of Bufo marinus in Australia. As the prevalence of positive antibodies was generally low, it was important to confirm the status of the ELISA positive sera. A small number of sera were tested by immunofluorescence. The fluorescent patterns were similar to those described for EHNV (Hyatt et al. 1991) and correspond to intracellular and extracellular viruses in addition to intracellular virus aggregates (data not shown). Immunoelectron microscopy also confirmed that the antibodies were virus specific. These resuits confirm that ELISA positive sera have antibodies specific to 'ranaviruses'. Collectively, the data presented in this paper show that Australian populations of $B$. marinus are infected with a 'ranavirus'. It should be noted that polyclonal antibodies against ranaviruses do not contain significant neutralising characteristics; this prevents the use of classical neutralisation assays for the identification of the infectious agent(s).

In Venezuela, 240 sera were found to be 'ranavirus' antibody-positive. These were collected from toads both east and west of the Andes. Whilst no positive sera were detected in southern Venezuela, it should be noted that very few samples were collected in this area. The isolation of a virus(es) (Guatopo virus, GV), from Venezuelan toads (Zupanovic et al. 1998) and the broad distribution of sero-positive animals within the country are significant findings. How long the toad populations have been infected is not known. It is not known if other populations of Bufo marinus in Texas, Mexico, Brazil, Peru, Guyana, Philippines, Papua New Guinea, Hawaii, Barbados, Jamaica, Puerto Rico and Fiji are also infected. Unpublished data from the Australian Animal Health Laboratory has indicated that GV can cause haematopoietic disease in tadpoles of $B$. marinus and in at least one species of Australian frog Litoria infrafrenata (Parkes \& Hyatt pers. comm.). In addition GV is different to BIV at the genomic and polypeptide level (Zupanovic et al. 1998).

The question therefore arises as to the identity of the virus that induces the antibody response in Australian Bufo marinus. The virus may be an endemic ranavirus such as BIV. BIV was isolated in a suburb of Townsville called Bohle. A serological survey in Townsville detected antibodies against ranaviruses (3/21 or $14 \%)$. However there may also be an 'exotic' virus that was imported with the original toads (e.g. GV) or imported by an unknown host. If the virus had been imported with the original toads, then the virus would have survived a complex set of events. The original toads (101) came indirectly from South America by a process of 'island hopping', i.e. Guyana to Barbados, Barbados to Puerto Rico, Puerto Rico to Hawail and then from Hawaii to Australia. Within Australia the toads, which showed no signs of disease, were bred and the progeny released along the north-east coast of Australia (Easteal 1983, Tyler 1994). If the virus had been released into the Australian environment, then it would have been introduced into the above countries, been carried in healthy toads and then transmitted to the progeny.

As Bufo marinus extends its range into the Northern Territory and further south into New South Wales, it has the potential to carry a broad range of infectious agents. Known infectious agents associated with $B$. marinus in other countries include viruses, bacteria, fungi, protozoa and helminths (Speare 1990). The viruses include an erythrocytic iridovirus (an unclassified group of iridoviruses) from Costa Rica (Speare et al. 1991) and a Toddia spp. (Pereira et al. 1973) that, although described as a protozoan, is probably a virus (Speare et al. 1991). Of the remaining agents, Aeromonas hydrophila, Salmonella spp., Bacillus spp., 2 Mycobacterium spp., Fusobacterium necrophorum, Fonsecaea pedrosoi, Spirametra mansoni, Trichodina spp. and Rhabdias spherocephala have been identified as causing pathological changes in $B$. marinus or diseases in other amphibians, fish or mammals (Hird et al. 1981, Speare 1990, Hau et al. 1992, Subasinghe 1992, Twiddy \& Reilly 1994, Prasad \& Rao 1995). Infectious agents which have been identified in/with $B$. marinus within Australia include species of protozoa, helminths and fungi (Delvinquier 1986, Freeland et al. 1986, Delvinquier \& Freeland 1988a, b, Speare 1990, Speare et al. 1994). A notable pathogen is Mucor amphibiorum (Speare et al. 1997). M. amphibiorum can cause ulcerative dermatitis and septicemia in freeranging platypus Ornithorhynchus anatinus (Obendorf et al. 1993) and it is also recognised as a possible pathogen of most Australian anurans (Speare et al. 1997). Whilst Australian B. marinus has not been reported to be infected with any protozoan of known pathogenicity, Trichodina spp. is identified as a pathogen of fish (Avault 1996). The above list of potentially pathogenic organisms illustrates the potential for a free-ranging species such as $B$. marinus to be a vector for disease. It is, however, the presence of a 'ranavirus(es)' within Australian B. marinus populations that could be of major environmental concern.

This concern is based on the pathogenic characteristics of 'ranaviruses' (Speare \& Smith 1992, Cullen et al. 1995, Drury et al. 1995, Ahne et al. 1997). The significance of the data presented in this paper will be known only when the epidemiology of the 'ranaviruses' infecting cane toads is understood. If the 
native aquatic fauna (within and outside) the current range of Bufo marinus is sero-negative to 'ranaviruses', then the transmission of a pathogenic virus(es) could signal a significant environmental problem.

Acknowledgements. The authors thank Ms Susie Daglas and Ms Julia Hammond for their technical assistance.

\section{LITERATURE CITED}

Ahne W, Bremont $M$, Hedrick RP, Hyatt AD, Whittington RJ (1997) Iridoviruses associated with epizootic haematopoietic necrosis (EHN) in aquaculture. World J Microbiol Biotechn (in press)

Avault JW Jr (1996) Understanding protozoans and disease caused by protozoans. Aquacult Mag 22:65

Covacevich J, Archer M (1975) The distribution of the cane toad, Bufo marinus, in Australia and its effects on indigenous vertebrates. Mem Queensl Mus 17:305-310

Cullen BR, Owens L, Whittington RJ (1995) Experimental infection of Australian anurans (Limnodynastes terraereginae and Litoria latopalmata) with Bohle iridovirus. Dis Aquat Org 23:83-92

Cunningham AA (1996) Disease risks of wildlife translocations. Conserv Biol 10:349-353

Delvinquier BLJ (1986) Myxidium immersum (Protozoa: Myxosporea) of the cane toad, Bufo marinus, in Australian Anura, with a synopsis of the genus in amphibians. Aust $J$ Zool 34:843-853

Delvinquier BLJ, Freeland WJ (1988a). Protozoan parasites of the cane toad, Bufo marinus, in Australia. Aust $\mathrm{J}$ Zool 36: $301-316$

Delvinquier BLJ, Freeland WJ (1988b) Observations on Zelleriella antilliensis (Protozoa: Opalinata) from the cane toad, Bufo marinus, in Australia. Aust J Zool 36:317-333

Drury SEN, Gough RE, Cunningham AA (1995) Isolation of an iridovirus-like agent from common frogs! Rana temporaria). Vet Rec 137:72-73

Easteal S (1983) The history of introductions of Bufo marinus (Amphibia: Anura): a natural experiment in evolution. Biol J Linn Soc 16:93-113

Fijan N, Matasin Z, Petrinec Z, Valpotic I, Zwillenberg LO (1991) Isolation of an iridovirus-like agent from the green frog (Rana esculenta L). Vet Arch Zagreb 3:151-158

Freeland WJ (1985) The need to control cane toads. Search 16:211-215

Freeland WJ (1986) Populations of cane toad, Bufo marinus, in relation to time since colonisation. Aust Wildl Res 13: $321-329$

Freeland WJ (1987) Cane toads and balance of nature. Wildl Aust 24:12-15

Freeland WJ, Delvinquier BLJ, Bonnin B (1986) Food and parasitism of the cane toad, Bufo marinus, in relation to time since colonization. Aust Wildl Res 13:489-499

Goorha R (1995) Virus taxonomy: the classification and nomenclature of viruses. In: Murphy FA, Fauquet CM, Bishop DHL, Ghabrial SA, Jarvis AW, Martelli CP, Mayo MA, Summers MD (eds) The Sixth Report of the International Committee on Taxonomy of Viruses. SpringerVerlag, Wien, p 95-99

Granoff A, Came PE, Breeze DC (1966) Viruses and renal carcinoma of Rana pipiens. I. The isolation and properties of virus from normal and tumor tissue. Virology 29:133-148

Hau LB, Liew MH, Yeh L (1992) Preservation of grass prawns by ionising radiation. J Food Prod 55(3):198-202
Hengstberger SG, Hyatt AD, Speare R, Coupar BEH (1993) Comparison of epizootic haematopoietic necrosis and Bohle iridoviruses, recently isolated Australian iridoviruses. Dis Aquat Org 15:93-107

Hird DW, Diesch SL, Mckinnell RG, Gorham E, Martin FB, Kurtz SW, Dubrovolny C (1981) Aeromonas hydrophila in wild-caught frogs and tadpoles (Rana pipiens) in Minnesota Lab. Anim Sci 31:166-169

Hyatt AD, Eaton BT, Hengstberger SM, Russel G (1991) Epizootic haematopoietic necrosis virus: detection by ELISA, immunocytochemistry and immunoelectron microscopy. J Fish Dis 14:605-617

Langdon JS, Humphrey JD, Williams LM, Hyatt AD, Westbury HA (1986) First virus isolation from Australian fish: an iridovirus-like pathogen from redfin perch, Perca fluviatilis L. J Fish Dis 9:263-268

Laurance WF, McDonald KR, Speare R (1996) Epidemic disease and the catastrophic decline of Australian rain forest frogs. Conserv Biol 10:406-413

Moody NJG, Owens L (1994) Experimental demonstration of the pathogenicity of a frog virus, Bohle iridovirus, for a fish species, barramundi Lates calcarifer. Dis Aquat Org 18: 95-102

Obendorf DL, Peel BF, Munday BL (1993) Mucor amphibiorum infection in platypus (Ornithorhynchus anatinus) from Tasmania. J Wildı Dis 29:458-487

Pereira NDeM, Costa SCG, De Sosa MA (1973) Toddia sp., 'corpusculo paranuclear' no sangue de Leptodactylus e Bufo do Brasil - desenvolvimento e citaquimico. Mem Inst Oswaldo Cruz 71:19-31

Prasad MM, Rao CCP (1995) Occurrence of Salmonella infantis and $S$. newport in market prawns. J Food Sci Tech 32(2): 135-137

Speare R (1990) A review of the diseases of the cane toad, Bufo marinus, with comments on biological control. Aust Wildl Res 17:387-410

Speare R, Berger L, O'Shea PO, Ladds PW, Thomas AD (1997) The pathology of mucormycosis of free-ranging Cane toads (Bufo marinus) in Australia. J Wildl Dis 33:105-111

Speare R, Freeland WJ, Bolton S (1991) A possible iridovirus in erythrocytes of Bufo marinus in Costa Rica. J Wildl Dis $27: 457-462$

Speare R, Smith JR (1992) An iridovirus-like agent isolated from the ornate burrowing frog Limnodynastes ornatus in northern Australia. Dis Aquat Org 14:51-57

Speare R, Thomas AD, O'Shea PO, Shipton JR (1994) Mucor amphibiorum in the toad, Bufo marinus, in Australia. $\mathrm{J}$ Wild Dis 30:399-407

Subasinghe RP (1992) Hatchery disease of freshwater fish in Sri Lanka. In: Sharrif M, Subashinge RP, Arthur JR. (eds) Proceedings of the First Symposium on Disease in Asian Aquaculture, 26-29 Nov 1990, Bali, Indonesia. Philippines Fish Health Section, Asian Fisheries Society, Manila, p 209-214

Twiddy DR, Reilly PJA (1994) Occurrence of antibioticresistant human pathogens in integrated fish farms. FAO Indo-Pacific Fishery Comm., Bangkok Research Contribution Presented at the Ninth Session of the Indo-Pacific Fishery Commission Working Party on Fish Technology and Marketing. Cochin, India 7-9 March 1994. Rome FAO 1995. Suppl 514, p 23-37

Tyler MJ (1994) The cane toad. In: Halbmeyer M (ed) Australian frogs, a natural history, 3rd edn. Reed Books, Griffin Press, Australia, p 104-127

Whittington RJ, Hyatt AD (1997) Contingency planning for control of epizootic haematopoietic necrosis virus. Singapore Vet $J$ (in press) 
Whittington RJ, Kearns C, Speare R (1997) Detection of antibodies against iridoviruses in the serum of amphibian Bufo marinus. J Virol Meth (in press)

Wolf K, Bullock GL, Dumbar DE, Quimby MC (1968) Tadpole edema virus: a viscerotropic pathogen for anuran amphib-

Editorial responsibility: Peernel Zwart,

Utrecht, The Netherlands ians. J Infect Dis 118:253-262

Zupanovic Z, Musso C, Lopez G, Louriero CL, Hyatt AD, Hengstberger S, Robinson AJ (1998) Isolation and characterisation of indoviruses from the giant toad Bufo marinus in Venezuela. Dis Aquat Org (in press)

Submitted: August 29, 1997; Accepted: October 13, 1997 Proofs received from author(s): January 23, 1998 